\title{
SBR 1/2005 SPECIAL SECTION
}

\section{EDITORIAI}

In September 2003, the German Economic Association of Business Administration, GEABA e.V., organized the IV. Symposium on the Economic ANALYsis of the Firm at the Johann Wolfgang Goethe-University Frankfurt am Main. The aim of these annual conferences is to serve as a forum to foster interdisciplinary application and development of an economic approach to problems in business administration. The papers given at that conference used instruments and methods of industrial economics, game theory, empirical economics, experimental designs, new institutional economics, and economic psychology to study business problems. Research issues focused on various fields such as finance, corporate policy, internal or intrafirm organization, accounting, and strategic management. The papers are indicative of the variety of interesting research issues and economics-oriented methodologies covered by the GEABA conference. The October 2004 issue of Schmalenbach Business Review contained three articles and the discussions presented at the conference. This January 2005 issue includes two more articles and their discussions. Both articles study incentive problems in firms. All published papers were subject to the standard referee process at Schmalenbach Business Review.

The first article is by Gunther Friedl, who studies the design of performance measures that can provide investment incentives for an impatient manager in the presence of real options. If a manager can invest in a project either immediately or at a later period, he or she has an option to wait that is not normally taken into account in the residual income measures. Friedl provides two potential solutions to internalize this real option. One recognizes the option value in the first period. The second increases the cost of capital charge of the project. Robert Göx provides the discussion of this article.

The second article by Eberhard Feess, Sonja Ossig, and Markus Walzl studies a principal-agent model in which the manager exerts effort to collect information about the profitability of projects. The principal designs an optimal incentive scheme for the manager to motivate him or her to work hard and truthfully report his or her private information. Feess, Ossig, and Walzl show that if the probability of a good project increases, the principal can be worse off because the cost of providing appropriate incentives overcompensates the better project situation. Ralf Ewert discusses this article.

The local organizer of the IV. Symposium, Prof. Dr. R. H. Schmidt and his team, as well as the sponsors the Ehlerding Stiftung, Dresdner Bank AG, and International Project Consult $\mathrm{GmbH}$, have our special thanks for making this conference a success. The members of the scientific advisory board of the GEABA and the conference discussants handled the referee process and the discussion of the conference, and without their work this symposium would not have possible. Finally, we would thank the anonymous reviewers of the Schmalenbach Business Review.

PETER-J. JOST

ALFRED WAGENHOFER

Special Section Editors 